Spectacular Nature 



\title{
Spectacular Nature
}

Corporate Culture

and the Sea World Experience

\author{
Susan G. Davis
}

UNIVERSITY OF CALIFORNIA PRESS

Berkeley / Los Angeles / London 
University of California Press

Berkeley and Los Angeles, California

University of California Press, Ltd.

London, England

(C) 1997 by

The Regents of the University of California

\section{Library of Congress Cataloging-in-Publication Data}

Author name. Davis, Susan G., 1953-

Spectacular nature: corporate culture and the Sea World experience / Susan G. Davis

p. $\mathrm{cm}$.

Includes bibliographic references and index.

ISBN O-52O-2003I-4 (cloth: alk. paper). ISBN O-\$2O-2098I-8 (pbk: alk. paper)

I. Sea World. 2. Amusement parks-Social aspects-CaliforniaSan Diego. 3. Amuscment parks-Economic aspects-CaliforniaSan Diego. 4. Corporate culturc-California-San Diego. I. Title. GVI853.C22S434 1996

$790^{\prime} .06^{\prime} 8^{\prime} 09794985-$ dc2 0

$$
96-44902
$$

Printed in the United States of America

$\begin{array}{lllllllll}9 & 8 & 7 & 6 & 5 & 4 & 3 & 2 & \text { I }\end{array}$

The paper used in this publication mects the minimum requirements of American National Standards for Information Sciences-Permanence of Paper for Printed Library Materials, ANSI Z39.48-I984.잉 
For Mary Ann and Dan, Lucy, and Ethan

my beautiful reward 
